(c) American Dairy Science Association, 2004.

\title{
Contribution of Native Pasture to the Sensory Properties of Ragusano Cheese*
}

\author{
S. Carpino, ${ }^{1}$ J. Horne, ${ }^{1}$ C. Melilli, ${ }^{1}$ G. Licitra, ${ }^{1,2}$ \\ D. M. Barbano, ${ }^{3}$ and P. J. Van Soest ${ }^{4}$ \\ ${ }^{1}$ CoRFiLaC, \\ Regione Siciliana, 97100 Ragusa, Italy \\ ${ }^{2}$ Dipartimento di Scienze Agronomiche, \\ Agrochimiche e delle Produzioni Animali, \\ Catania University, Via Valdisavoia 5, 95100 Catania, Italy \\ ${ }^{3}$ Northeast Dairy Foods Research Center, \\ Department of Food Science, \\ Cornell University, Ithaca, NY 14853 \\ ${ }^{4}$ Department of Animal Science, \\ Cornell University, Ithaca, NY 14853
}

\section{ABSTRACT}

Ragusano is a Protected Denomination of Origin cheese produced in the Hyblean area of Sicily. Sixteen samples of Ragusano cheese from two different treatments [pasture and total mixed ration (TMR)] were evaluated after 4 and 7 mo of aging. The color of the cheeses produced from milk of cows consuming fresh native pasture plants was much more yellow than cheeses from TMR fed cows (i.e., higher Hunter $b$ value). This was due to transfer of $\beta$-carotene and related compounds from the diet and demonstrated that compounds from native pasture plants changed the sensory characteristics of Ragusano cheese. To avoid a "halo" effect in a trained panel, quantitative descriptive analysis sensory evaluation of these cheeses for odor, taste, consistency, and mouth structure, color differences among cheeses were masked. A unique approach in sensory analysis was developed using sunglasses with lenses designed to block light at the specific wavelengths at which panelists would detect differences in color among samples. Testing was conducted every 2 -wk period (15-d increments) with two tests per week using 11 trained panelists. All the panelists tasted all the products. Panelists were able to detect significant differences in the sensory characteristics of cheeses produced from milk of cows con-

Received February 9, 2003.

Accepted June 5, 2003.

Corresponding author: D. M. Barbano; e-mail: dmb37@cornell.edu.

*Use of names, names of ingredients, and identification of specific models of equipment is for scientific clarity and does not constitute any endorsement of product by authors, Cornell University, the Northeast Dairy Foods Research Center, CoRFiLaC, and Dipartimento di Scienze Agronomiche, Agrochimiche e delle Produzioni Animali, Catania University. suming native pastures versus TMR even when the color difference was masked.

(Key words: pasture, cheese, sensory, color)

\section{INTRODUCTION}

Ragusano cheese is a natural product, the fruit of multigenerational experience of the local cheese makers, in which the characteristics of quality are derived from human and natural factors related to the Hyblean region. It is an ancient cheese that still has a vibrant role in the present culture. In the world of the masserie (farmstead cheese-making), cheese makers continue to bring together the bounty of nature and the experience of generations of cheese makers responding to the demands of the current economic conditions and the rigors of the technological science. The traditional cheese-making process for Ragusano is characterized by the following factors: the use of whole raw milk; the presence of beneficial natural bacteria; the use of natural rennet produced with artisan techniques; the use of artisan cheese-making tools hand made from wood and copper (i.e., tina, rotula, caurara, staccio, manovella, mastredda, and muolito); the cheese-aging process, which is traditionally done in natural locations; and the physical shaping of the product (Licitra et al., 1998). We define those factors including the native breed of dairy cattle and the use of natural pasture of the Hyblean region, as characters of biodiversity. It is the man, the cheese maker, the artist, who must prepare himself daily to react and guide the equilibrium of all these natural processes, in knowing the delicate harmony of the sequence of actions and timing of the cheese-making process to guarantee the production of a cheese of excellent quality (Licitra et al., 2000b). 
Ragusano cheese is a brine-salted pasta filata cheese that is made by traditional cheese manufacturing procedures that were described (Licitra et al., 1998). Ragusano cheese can be aged up to $12 \mathrm{mo}$; however, it is common to sell the cheese at 4 to 6 mo as semi-aged and at greater than 6 mo as an aged cheese. Composition variation within blocks is large (Licitra et al., 2000a) due to salt and moisture gradients developed during brine salting.

The diet of dairy cattle can influence the color of cheese. Seasonal variation in the color of cheese is related to changes in the concentration of $\beta$-carotene in milk (Kosikowski and Mistry, 1997). In general, consumption of green forages increases the $\beta$-carotene content of milk and cheese (Panfili et al., 1994). There is also a large body of anecdotal evidence about the desirable effect of spring and summer grasslands on the distinctive flavor of dairy products (Wigan, 1951), but little work has been done to define the flavor difference in terms of specific flavor compounds. French workers (Dumont et al., 1981) have shown that Gruyère de Comté cheese typically contains sesquiterpene hydrocarbons in summer, but not in winter. Dumont et al. (1981) compared samples of Gruyère de Comté made from milk originating from mountains, plateaus, and plains and showed that mountain cheeses were the richest in volatile compounds and typically contained terpenes and sesquiterpenes. Neither of these studies reported analyses of the corresponding feeds to see whether the differences were due to direct transfer of these compounds from the feed or whether the additional compounds were formed or modified in the cow. Flavor substances may be transferred to the milk directly through inhaled air into the blood and from there to the milk; through the fodder and digestive tract; or via rumen gases to blood and milk (Dougherty, 1962). The unique character of some cheeses may come from the environmental conditions of milk production (Urbach, 1990). Some compounds from plants may contribute to the formation of desirable flavors in the cheese due to the action of enzymes contributed by the microflora of the cheese. Secondary compounds in plants, or derivatives of those compounds created by the fermentation process in the rumen, may be transmitted through the cow to the milk. There may be a relationship between these compounds and the flavor or odor of cheese. The objective of this study was to determine whether inclusion of native pastures in the diet of dairy cows changes the color, odor, taste, consistency, or mouth structure of Ragusano cheese.

\section{MATERIALS AND METHODS}

\section{Experimental Design}

The period of the study was from February to May 1999. One group of 13 Friesian cows on one farm was
Table 1. Average daily feed consumption and composition data for the cows fed a TMR and a TMR plus pasture diet.

\begin{tabular}{lcc}
\hline & $\begin{array}{c}\text { TMR + } \\
\text { pasture }\end{array}$ & TMR \\
\hline Diet (TMR + pasture) in kg & & \\
Rye grass hay & 3.69 & 4.26 \\
Mix 1 & 5.19 & 5.99 \\
Mix 2 & 4.51 & 5.21 \\
Corn meal & 0.74 & 0.85 \\
Corn silage & 4.53 & 5.24 \\
TMR intake (DM) & 18.64 & 21.54 \\
Pasture intake (DM) & 3.07 & 0 \\
Diet composition from CNCPS & & \\
NE (Mcal/kg) & & 1.72 \\
CP (\% DM) & 1.68 & 16.26 \\
Soluble CP (\% CP) & 16.20 & 28.15 \\
RDP (\% CP) & 28.34 & 63.68 \\
NFC (\% DM) & 63.31 & 37.85 \\
NDF (\% DM) & 37.25 & 37.32 \\
ENDF $(\%$ DM) & 37.48 & 26.71 \\
\hline
\end{tabular}

${ }^{1}$ Mix 1 = Lattifera 12 = Cereal grains, cereal byproducts, products and byproducts of oil seeds, products and byproducts of sugar, minerals, methionine, BHT (butylated hydroxytoluene) and etossichin.

${ }^{2}$ Mix 2 = Nucleo vacche = Products and byproducts of oil seeds, products and byproducts of cereal grains, oil seeds, cereal grains, products and byproducts of sugar, oil and fat, calcium salts, food fat, minerals, methionine, BHT (butylated hydroxytoluene) and etossichin.

${ }^{3}$ CNCPS $=$ Cornell Net Carbohydrate and Protein System.

${ }^{4} \mathrm{ENDF}=$ Effective NDF.

fed a TMR and another group of 13 Friesian cows on the same farm received some TMR plus grazed on native pasture. The two groups of cows were balanced for parity and the mean parity for both groups was 2.23. Cows were in late lactation, with a mean BW of $650 \mathrm{~kg}, \mathrm{BCS} 3.15$, and were producing an average of $25 \mathrm{~kg}$ of milk per day with a fat content of about $3.7 \%$ and a CP content of about 3.0\%. A group of cows with positive balance energy (anabolic phase), at least $100 \mathrm{~d}$ of lactation was selected to avoid the body mobilization factor. This could interfere in the experiment because some of the aromatic compounds in the fat tissue might be released. One group was fed a TMR and the other group received some TMR plus grazed on native pasture. Daily grazing time was approximately $7 \mathrm{~h} / \mathrm{d}$. The average consumption and composition of the diets for the two groups are provided in Table 1. The DMI of the cows on TMR was approximately $21.54 \mathrm{~kg} / \mathrm{d}$. The cows on pasture consumed about $18.64 \mathrm{~kg}$ of DM from TMR and $3.07 \mathrm{~kg}$ from pasture per day. The most common plants in the pasture in terms of both occurrence and selection by the cows were Calendula arvensis (Asteraceae), Geraniaceae (various species), Graminaceae (various species), unspecified short Asteraceae, and Fabaceae (various species). These comprised about $60 \%$ of the plant material selected by the cows on DM basis. 
Milk was collected separately from each group, and cheese was made four times, once every $2 \mathrm{wk}$. The details of the cheese-making method and aging were described elsewhere (Melilli et al., 2003) except for the following differences. About $300 \mathrm{~L}$ of raw whole milk was used for each treatment, in order to obtain two blocks of Ragusano cheese of $14 \mathrm{~kg}$ from each vat. Natural rennet from the stomach of lambs was used in this experiment (Provo 5, Caglificio Clerici s.p.a., Cadorago, Co, Italy). The temperature of the curd at the end of the second cooking was $45^{\circ} \mathrm{C}$, and the curd was left to ripen for $19 \mathrm{~h}$. After ripening, the curd reached a $\mathrm{pH}$ of 5.0 to 5.1. The temperature of the curd after stretching was $42^{\circ} \mathrm{C}$ due to the large amount of curd to be stretched (about $14 \mathrm{~kg}$ ). Two 14-kg blocks of Ragusano cheese were produced for each treatment at each cheese making for a total of eight blocks of cheeses for each treatment. The blocks from the two treatments were placed in separate saturated salt brine tanks at $18^{\circ} \mathrm{C}$ for $21 \mathrm{~d}$. After removal from the brine the cheeses were aged at $15^{\circ} \mathrm{C}$.

At 4 mo of age, each 14-kg block was cut in half. The first half was used for color and sensory analysis at 4 mo, whereas the second half was aged and evaluated again for color at $7 \mathrm{mo}$. The cut surface of the second half of the block was sealed with Rindol A (Paramelt B. V. Heerhugowaard, The Netherlands) to protect the cut surface during further aging and to avoid mold growth.

\section{Feed Analyses}

Analyses of the feeds were done using the following methods: CP (AOAC, 1990; method number 954.01), NDF (Van Soest et al., 1991), and soluble protein (Licitra et al., 1996). The effective NDF, ruminally degradable protein, nonfiber carbohydrate, and $\mathrm{NE}_{\mathrm{L}}$ content of the two diets were calculated using the Cornell Net Carbohydrate and Protein System (Fox et al., 1992).

\section{Measurement of Cheese Color}

A Macbeth Color-Eye Spectrophotometer (model 2020; Kollmorgen Instruments Corp., Newburgh, NY) was used to measure the color of cheeses from the two treatments (pasture and TMR) and to calculate Hunter $\mathrm{L}$, $\mathrm{a}$, and $\mathrm{b}$ values based on illuminate $\mathrm{A}$, which is an incandescent lamp. The percentage of light reflected over the wavelength range from 360 to $740 \mathrm{~nm}$ (in 10$\mathrm{nm}$ increments) was measured. Hunter $\mathrm{L}$, $\mathrm{a}$, and $\mathrm{b}$ values were calculated. Two samples were analyzed for each cheese. The cheese samples were cut in slices $(4 \times 4 \times 1 \mathrm{~cm})$ and vacuum packed. The samples were equilibrated for $1 \mathrm{~h}$ to $21^{\circ} \mathrm{C}$ in a water bath immediately before color analysis.

\section{Sensory Analysis}

Upon visual examination of the cheeses from the pasture and TMR dietary treatments by the researchers, it was clear that there was a large difference in the color of the cheeses due to diet. It has been documented previously in sensory research that color differences among products, particularly when panelists have preexisting ideas of how color relates to the sensory quality of a product, can produce a "halo" effect that will distort evaluations of differences in odor, taste, and texture (Phillips et al., 1995). To avoid the confounding effects of color differences among the cheeses due to the treatments, panelists evaluated the flavor, aroma, and texture of cheeses in subdued light wearing glasses (postmydriatic sunglasses, Solarettes, Optics and Service Centrostyle, Italy), designed to block the wavelengths of reflected light that allowed panelists to distinguish color differences among these cheeses. The light transmission spectra of the sunglasses was measured by inserting a lens from the glasses in a UV/ visible spectrophotometer and measuring the percent transmittance of light at wavelengths from 360 to $700 \mathrm{~nm}$.

Eleven panelists, from the staff of CoRFiLaC in Ragusa, Italy, were trained for quantitative descriptive sensory analysis (O'Mahony, 1986) during several sessions in which descriptive terms were generated through group discussion for odor, taste, consistency, and mouth structure attributes of Ragusano cheese. Redundant terms were eliminated and consensus was developed for the meanings of the descriptors. By selecting terms with the highest correlation with differences in samples used in training, a single score card containing nine odor, eight taste, five consistency, and four mouthfeel descriptors was developed representing the consensus profile of sensory characteristics (Table 2). Attributes were evaluated on 15-point intensity scales with labels at the left and right ends to indicate the direction of the scales. Tasting was conducted every 2-wk period (15-d increments) using 11 trained panelists. All the panelists tasted all the products at 4 mo of age in subdued light while wearing the glasses designed to mask color differences. In all tests, cheese cube samples $\left(1 \mathrm{~cm}^{3}\right)$ were kept in a water bath at $18^{\circ} \mathrm{C}$ for $1 \mathrm{~h}$ and served in a randomized order on paper plates at $21^{\circ} \mathrm{C}$. The trained panel was given samples of cheeses from the two treatments (pasture and TMR). The samples were labeled with A and B codes, and the panelists were not provided with information regarding the treatment of each sample.

\section{Statistical Analysis}

Two-way ANOVA were performed for the Hunter L, $a$, and $b$ values, and the percentage reflectance data 
Table 2. Definitions and scales for sensory terminology used to describe Ragusano cheese.

\begin{tabular}{|c|c|c|c|}
\hline Odor & $\begin{array}{l}\text { Smell the sample and evaluate } \\
\text { the following attributes. }\end{array}$ & Taste & $\begin{array}{l}\text { Taste the sample and evaluate } \\
\text { the following attributes. }\end{array}$ \\
\hline Pungent & $\begin{array}{l}\text { Irritating sharp sensation in the nose. } \\
\text { low } \rightarrow \text { high }\end{array}$ & Pungent & $\begin{array}{l}\text { Irritating sharp sensation in the nose caused by short } \\
\text { chain fatty acids (e.g., butyric). } \\
\text { low } \rightarrow \text { high }\end{array}$ \\
\hline Butter & $\begin{array}{l}\text { The clean, fatty, mild flavor of fresh butter. } \\
\text { low } \rightarrow \text { high }\end{array}$ & Sweet & $\begin{array}{l}\text { One of the five primary tastes characteristic of simple } \\
\text { sugars (e.g., sucrose). } \\
\text { low } \rightarrow \text { high }\end{array}$ \\
\hline Floral & $\begin{array}{l}\text { Reminiscent of cut fresh flowers. } \\
\text { low } \rightarrow \text { high }\end{array}$ & Salt & $\begin{array}{l}\text { One of the five primary tastes characteristic of } \\
\text { sodium chloride. } \\
\text { low } \rightarrow \text { high }\end{array}$ \\
\hline $\begin{array}{l}\text { Green/ } \\
\text { herbaceous }\end{array}$ & $\begin{array}{l}\text { Reminiscent of green leaves and grass just cut. } \\
\text { low } \rightarrow \text { high }\end{array}$ & Acid & $\begin{array}{l}\text { One of the five primary tastes characteristic of acidity. } \\
\text { low } \rightarrow \text { high }\end{array}$ \\
\hline Almond & $\begin{array}{l}\text { Aroma characteristic of fresh almonds. } \\
\text { low } \rightarrow \text { high }\end{array}$ & Bitter & $\begin{array}{l}\text { One of the five primary tastes characteristic of } \\
\text { caffeine, quinine, and certain other alkaloids. } \\
\text { low } \rightarrow \text { high }\end{array}$ \\
\hline $\begin{array}{l}\text { Mushroom/ } \\
\text { mold }\end{array}$ & $\begin{array}{l}\text { An aroma generally associated with fresh raw mushrooms, } \\
\text { with some characteristics described as damp earthy and musty. } \\
\text { low } \rightarrow \text { high }\end{array}$ & Astringent & $\begin{array}{l}\text { A sensation on the tongue and other oral surfaces } \\
\text { described as puckering/dry and associated with tannins or alum. } \\
\text { low } \rightarrow \text { high }\end{array}$ \\
\hline Toasted & $\begin{array}{l}\text { Aroma associated with a nutty, caramelized, browned } \\
\text { character of Maillard browned starches and sugar. } \\
\text { low } \rightarrow \text { high }\end{array}$ & Butyric & $\begin{array}{l}\text { Rancid aromatic associated with butyric acid. } \\
\text { low } \rightarrow \text { high }\end{array}$ \\
\hline Butyric & $\begin{array}{l}\text { Aroma typical of the rancid character of butyric acid as } \\
\text { opposed to the sharp/tingling sensations associated } \\
\text { with "pungency". } \\
\text { low } \rightarrow \text { high }\end{array}$ & Lingering & $\begin{array}{l}\text { Length of time after swallowing or expectorating } \\
\text { the sample the flavor persists in the mouth. } \\
\text { short } \rightarrow \text { long }\end{array}$ \\
\hline Odor intensity & $\begin{array}{l}\text { Overall aromatic intensity. } \\
\text { low } \rightarrow \text { high }\end{array}$ & & \\
\hline Consistency & $\begin{array}{l}\text { Manipulate a sample of cheese between } \\
\text { thumb and forefinger and } \\
\text { evaluate the following attributes. }\end{array}$ & Mouthfeel & $\begin{array}{l}\text { Place a new sample of cheese between } \\
\text { two teeth and chew as to swallow } \\
\text { evaluate the following attributes. }\end{array}$ \\
\hline Smooth/rough & $\begin{array}{l}\text { Degree to which the surface of the sample feels } \\
\text { smooth or rough to the touch. } \\
\text { very smooth } \rightarrow \text { very rough }\end{array}$ & Soft/hard & $\begin{array}{l}\text { Force required to compress sample when placed between } \\
\text { molar teeth. } \\
\text { very soft } \rightarrow \text { very hard }\end{array}$ \\
\hline \multirow[t]{2}{*}{ Oily } & \multirow[t]{2}{*}{$\begin{array}{l}\text { Degree to which the surface of the sample leaves an oily } \\
\text { residue on the skin when manipulated between the fingers. } \\
\text { low } \rightarrow \text { high }\end{array}$} & Saliva evoking & $\begin{array}{l}\text { Degree to which sample causes increased salivary } \\
\text { flow in the mouth. } \\
\text { recall saliva } \rightarrow \text { not recall saliva }\end{array}$ \\
\hline & & Dispersion & $\begin{array}{l}\text { Degree to which sample breaks into a few large } \\
\text { pieces or many small particles in the mouth during chewing. } \\
\text { large pieces } \rightarrow \text { small particles }\end{array}$ \\
\hline Plasticity & $\begin{array}{l}\text { Press down on the cheese with a forefinger. } \\
\text { Degree to which the sample returns to its original } \\
\text { shape after having been compressed. } \\
\text { low } \rightarrow \text { high }\end{array}$ & Teeth stickiness & $\begin{array}{l}\text { Degree to which sample adheres to teeth during chewing. } \\
\text { low } \rightarrow \text { high }\end{array}$ \\
\hline Soft/hard & $\begin{array}{l}\text { Compress the cheese between thumb and forefinger until it breaks. } \\
\text { Force required to compress sample when placed between } \\
\text { fingers. } \\
\text { low } \rightarrow \text { high }\end{array}$ & & \\
\hline Fracture & $\begin{array}{l}\text { Ease of which the sample breaks cleanly into two or } \\
\text { more pieces when compressed. } \\
\text { difficult } \rightarrow \text { easy }\end{array}$ & & \\
\hline
\end{tabular}


Table 3. The ANOVA models used for analysis of color and sensory data.

\begin{tabular}{llcll}
\hline Data & Model term & df & Analyzed & Error term \\
\hline Hunter values and & $\mathrm{F}$ & 1 & Fixed & Model error \\
percent reflectance & $\mathrm{W}$ & 3 & Fixed & Model error \\
& $\mathrm{F} * \mathrm{~W}$ & 3 & Interaction & \\
& $\mathrm{E}$ & 8 & Error & \\
Sensory analysis & Model equation: $\mathrm{Y}=\mathrm{F}+\mathrm{W}+(\mathrm{F} * \mathrm{~W})$ & $+\mathrm{E}$ & \\
& $\mathrm{Pn}$ & 10 & Block (random) & $\mathrm{Pn} * \mathrm{~F}$ \\
& $\mathrm{~F}$ & 1 & Fixed & $\mathrm{Pn} * \mathrm{~W}$ \\
& $\mathrm{~W}$ & 3 & Fixed & \\
& $\mathrm{F} * \mathrm{~W}$ & 3 & Interaction & \\
& $\mathrm{Pn} * \mathrm{~F}$ & 10 & Interaction & \\
& $\mathrm{Pn} * \mathrm{~W}$ & 30 & Interaction & Interaction \\
& $\mathrm{Pn} * \mathrm{~F} * \mathrm{~W}$ & 30 & Error & \\
& $\mathrm{E}$ & 88 & $\mathrm{~F}$ & \\
& $\mathrm{Model}$ Equation: $\mathrm{Y}=\mathrm{Pn}+\mathrm{F}+\mathrm{W}+(\mathrm{F} * \mathrm{~W})+(\mathrm{Pn} * \mathrm{~F})+(\mathrm{Pn} * \mathrm{~W})+(\mathrm{Pn} * \mathrm{~F} * \mathrm{~W})+\mathrm{E}$ \\
\hline
\end{tabular}

${ }^{1} \mathrm{~F}=$ Feed (Pasture and TMR), $\mathrm{W}=$ Week, $\mathrm{Pn}=$ Panelist, $\mathrm{E}=$ Error.

with feed type and week as whole plot fixed factors (Table 3). The repeated measure ANOVA model used for statistical analysis of the sensory data is listed in Table 3. In the sensory data analysis, the panelist term was treated as random variable. Analyses were done using SAS (SAS User's Guide, 1999).

\section{RESULTS AND DISCUSSION}

\section{Cheese Color}

The Hunter L, a, and b values for the Ragusano cheeses from pasture and TMR are shown in Table 4. The a values and the $b$ values for both ages, 4 and 7 mo, were significantly different for the pasture and TMR cheeses. The pasture cheeses were much more yellow (i.e., higher $b$ value) than the TMR cheeses. This is a clear demonstration that compounds from pasture plants transferred from diet to cheese and was an indication that there also may be transfer of flavor and color compounds that are unique to the plants of the region where the cheese was produced. Yellow col- ors originating from fresh plant materials are usually due to $\beta$-carotene and related carotenoid compounds. The average reflectance spectra for the TMR and pasture cheeses and the transmission spectra for the glasses used to block color differences during the sensory analysis are shown in Figure 1. There was a significant difference in the amount of reflected light at 460,480 , and $500 \mathrm{~nm}$ (Table 4) between pasture and TMR cheeses at $7 \mathrm{mo}$ and a similar trend was observed at 4 mo. The wavelength of peak light absorbance of $\beta$-carotene is $450 \mathrm{~nm}$ (Britton, 1995). These objective measures of color differences of the cheeses from the two treatments clearly justify the need to mask these differences in appearance to obtain an unbiased evaluation of odor, taste, consistency, and mouth structure during sensory analysis. The transmission spectra of the glasses used by the panelists during sensory analysis demonstrates that more than $96 \%$ of the reflected light at the wavelengths that would allow panelists to tell a color difference among the cheeses (i.e., 460 to $500 \mathrm{~nm}$ ) was blocked by the glasses (Figure 1). Thus,

Table 4. Hunter L, a, and b values and percentage of light reflected at 460, 480, and $500 \mathrm{~nm}$ of the pasture and TMR Ragusano cheeses at 4 and 7 mo.

\begin{tabular}{|c|c|c|c|c|c|c|}
\hline \multirow[b]{2}{*}{ Hunter Value } & \multicolumn{3}{|c|}{$4 \mathrm{mo}$} & \multicolumn{3}{|c|}{$7 \mathrm{mo}$} \\
\hline & Pasture & TMR & $\mathrm{LSD}^{1}$ & Pasture & TMR & $\mathrm{LSD}^{1}$ \\
\hline $\mathrm{L}$ & 79.12 & 78.62 & $\mathrm{NS}^{2}$ & 76.77 & 77.10 & $\mathrm{NS}^{2}$ \\
\hline $\mathrm{a}$ & $2.96^{\mathrm{a}}$ & $1.22^{\mathrm{b}}$ & 0.57 & $0.71^{\mathrm{a}}$ & $-0.58^{b}$ & 0.35 \\
\hline $\mathrm{b}$ & $11.54^{\mathrm{a}}$ & $8.96^{\mathrm{b}}$ & 0.45 & $16.14^{\mathrm{a}}$ & $12.91^{\mathrm{b}}$ & 0.15 \\
\hline \multicolumn{7}{|c|}{ Wavelength (nm) } \\
\hline 460 & $36.52 \%$ & $41.82 \%$ & NS & $35.05 \%^{b}$ & $40.71 \%^{\mathrm{a}}$ & 1.67 \\
\hline 480 & $38.70 \%$ & $44.76 \%$ & NS & $37.40 \%^{\mathrm{b}}$ & $43.91 \%^{\mathrm{a}}$ & 1.74 \\
\hline 500 & $43.50 \%$ & $50.10 \%$ & NS & $41.89 \%{ }^{\mathrm{b}}$ & $48.40 \%^{\mathrm{a}}$ & 2.07 \\
\hline
\end{tabular}

${ }^{\mathrm{a}, \mathrm{b}}=$ means within the same age not having a common superscript differ $(P<0.05)$.

${ }^{1} \mathrm{LSD}=$ least significant difference $(P<0.05)$.

${ }^{2} \mathrm{NS}=$ not significant. 

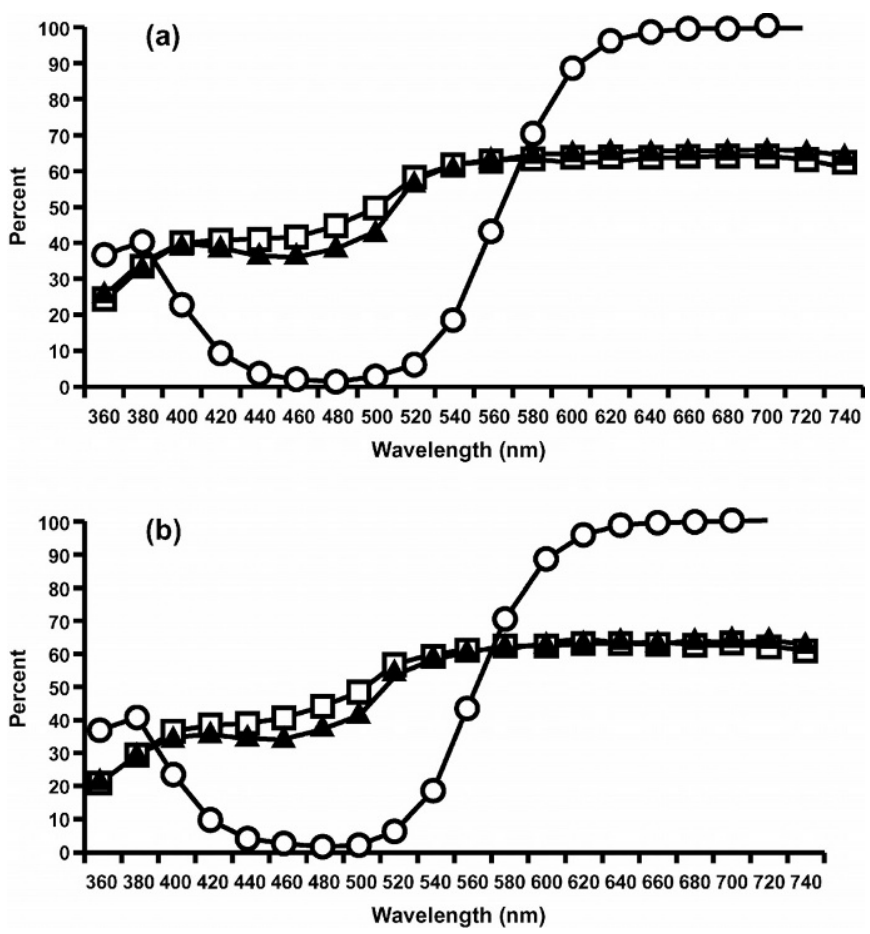

Figure 1. Average percent light reflected at wavelengths from 360 to $740 \mathrm{~nm}$ for pasture $(\mathbf{\Delta})$ and TMR ( $\square$ ) cheeses at 4 mo of age (a) and 7 mo of age (b) and percent light transmitted through lenses of glasses $(O)$ used in the sensory analysis to mask differences in color for Ragusano cheese.

the glasses were able to mask color differences among the cheese samples during sensory evaluation and avoid a "halo" effect on the evaluation of odor, taste, consistency, and mouthfeel.

\section{Cheese Odor, Taste, Consistency, and Mouthfeel}

The 26 descriptors used in the quantitative descriptive analysis were developed to describe differences in Ragusano cheese characteristics that are encountered in the market place. A wide variety of Ragusano cheeses with variation in sensory characteristics were used in training to ensure that the panelists would have adequate terms to describe differences that can exist among Ragusano cheeses. The current study was designed to control many of the sources of variation in that cause differences in cheese characteristics from one farm to another and seasonally. It must be recognized in the present study that most of those variables have been controlled and that this study focuses on trying to isolate the effect of feeding native pasture plants on the sensory characteristics of Ragusano cheese. As shown in the previous section, the pasture produced a highly significant effect on the color of the cheese. This effect was so pronounced that the color
Table 5. Mean intensity scores for pasture and TMR cheese at 4 mo of age.

\begin{tabular}{lllll}
\hline & & \multicolumn{3}{c}{ Intensity score } \\
\cline { 3 - 5 } & Descriptor & $\begin{array}{l}\text { Pasture } \\
\text { mean }\end{array}$ & $\begin{array}{l}\text { TMR } \\
\text { mean }\end{array}$ & LSD $^{1}$ \\
\hline Attribute: odor & & & & \\
& Floral & $3.03^{\mathrm{a}}$ & $2.33^{\mathrm{b}}$ & 0.61 \\
& Green/herbaceous & $2.93^{\mathrm{a}}$ & $2.26^{\mathrm{b}}$ & 0.64 \\
& & & & \\
& Ottribute: consistency & $3.31^{\mathrm{b}}$ & $3.83^{\mathrm{a}}$ & 0.43 \\
& Fracture & $7.39^{\mathrm{a}}$ & $6.60^{\mathrm{b}}$ & 0.60 \\
\hline
\end{tabular}

${ }^{1} \mathrm{LSD}=$ least significant difference $(P<0.05)$.

differences had to be masked and not evaluated in the quantitative descriptive analysis. If the color was not masked during the sensory analysis, all of the panelists would have known the treatments. Therefore, extreme care was taken to mask the color differences during sensory analysis in an attempt to achieve a valid comparison and detection of any nonvisual differences in the sensory characteristics of Ragusano cheese produced by the consumption of native pasture plants. Given the focused and controlled nature of this study, it is not surprising that there was no impact of the consumption of pasture plants on many of the sensory descriptors for Ragusano cheese.

The intensity scores for the sensory descriptors for Ragusano cheeses made from milk produced from cows on pasture and TMR diets that were significantly different at 4 mo are shown in Table 5. The intensity of the odor attributes of floral and green/herbaceous were higher $(P<0.05)$ for the 4 mo pasture than TMR cheeses. These odor descriptors are characteristic of volatile compounds normally associated with fresh pasture plants. The consistency attributes oily and fracture were also significantly different at $4 \mathrm{mo}$ for pasture and TMR cheeses. The pasture cheeses were less $(P<0.05)$ oily (3.31 vs. 3.83$)$ and less difficult to fracture $(P<0.05)$ than the TMR cheeses $(7.39$ vs. 6.60). The detailed results for the sensory attributes scored are also shown in a spider web format (Figure 2 ). Figure 2 (a, b, and c) shows the sensory profiles for the cheeses produced from milk of pasture and TMR fed cows at 4 mo age. The overall level of intensity for various attributes that characterize the odor, taste, and consistency and mouthfeel for Ragusano cheese can be seen from Figure 2.

Sensory data are not presented for the cheeses at 7 mo of age. As described in the materials and methods section, each block was cut in half. Half of the block of cheese was used for sensory analysis at 4 mo. Ragusano cheese is a cheese with a rind and is not aged in a vacuum package. Therefore, we attempted to use a self-hardening polymeric liquid coating on the cut 
(a)

(b)

(c)
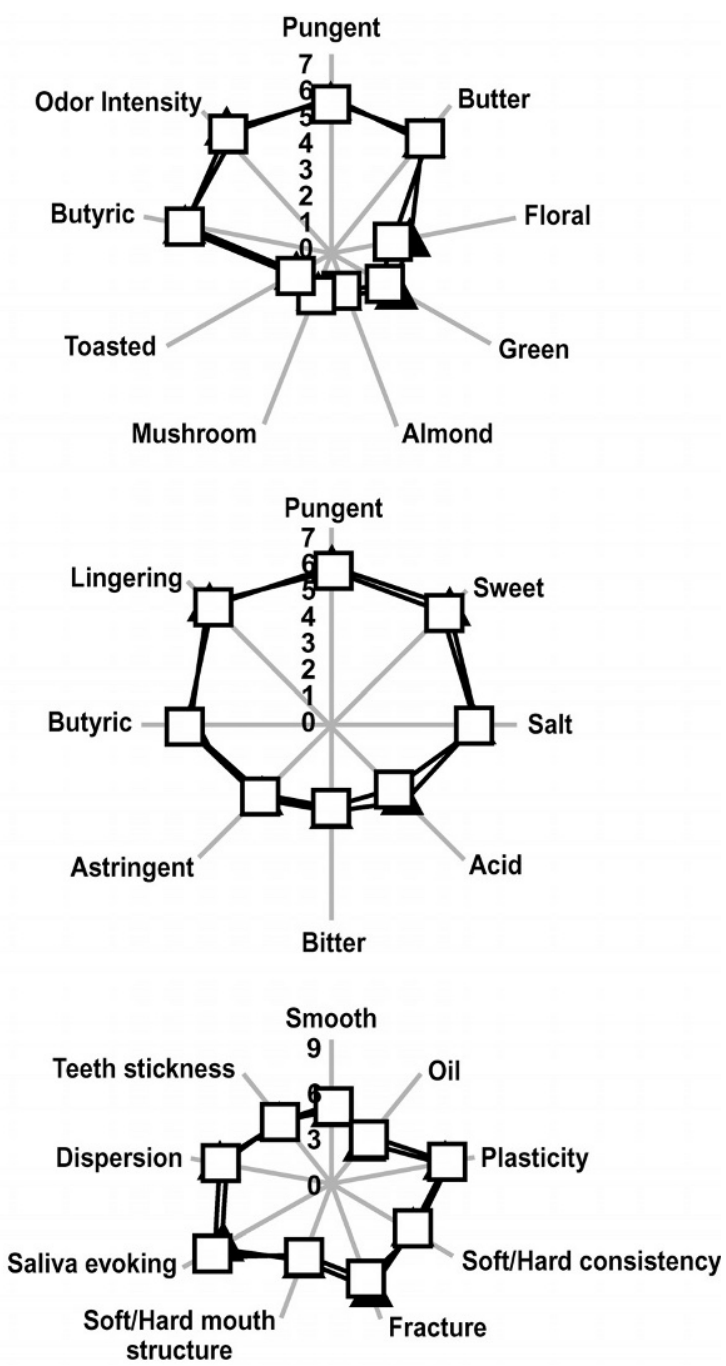

Figure 2. Sensory profiles of Ragusano cheeses produced from milk of pasture ( $\mathbf{\Delta}$ ) and TMR ( $\square$ ) fed cows; (a) odor, (b) taste, and (c) consistency and mouthfeel descriptors at 4 mo of age.

surface of each block of cheese that would allow moisture transmission during the next 3 mo of aging of the second half of the block, but prevent mold growth. It was successful for some blocks but not for others. Therefore, because of missing sensory data for some cheeses due to mold spoilage, a valid comparison of the sensory characteristics of the cheeses at 7 mo could not be made.

\section{CONCLUSIONS}

Cheeses made from milk produced by cows that consumed native pasture plants were more yellow than cheeses produced from TMR fed cows on the same farm. The range of wavelengths of light where diffuse reflectance differed the most among the pasture and
TMR cheeses was 460 to $500 \mathrm{~nm}$. The absorbance maximum for $\beta$-carotene and related carotenoids are in this range, and it is likely the $\beta$-carotene and related compounds contributed by fresh pasture plants caused the difference in color. When the color difference between pasture and TMR cheeses was masked during sensory analysis, panelists were still able to detect differences in odor and consistency attributes at 4 mo of aging. Therefore, consumption of native plants from fresh pasture by the cows influenced color and other sensory attributes of Ragusano cheese. Future work is needed to isolate and identify the specific chemical compounds responsible for the odor differences between cheeses made from milk produced by cows consuming pasture versus TMR.

\section{ACKNOWLEDGMENTS}

Financial support was provided by the Assessorato Agricoltura e Foreste della Regione Siciliana, Palermo, Italy.

\section{REFERENCES}

Association of Official Analytical Chemists International. 1990. Official Methods of Analysis. Vol.I. 15th ed. AOAC, Arlington, VA.

Britton, G. 1995. UV/visible spectroscopy. Chapter 2 in Carotenoids. Vol. 1 B: Spectroscopy. G. Britton, S. Liaaen-Jensen, and H. Pflander, eds. Birkhäuser Verlag, Basel, Switzerland.

Dougherty, R. W., W. F. Shipe, G. V. Gudnason, R. A. Ledford, R. D. Peterson, and R. Scarpellino. 1962. Phisiologycal mechanisms involved in transmitting flavours and odors to milk. I. Contribution of eructated gases to milk flavor. J. Dairy Sci. 45:472-476.

Dumont, J. P., J. Adda, and P. Rousseaux. 1981. Example of aroma variation within the same cheese: Gruyère de Comté. Lebensmittel Wissensch. Technol. 14:198-202.

Fox, D. G., C. J. Sniffen, J. D. O'Connor, J. B. Russell, and P. J. Van Soest. 1992. A net carbohydrate and protein system for evaluating cattle diets: III. Cattle requirements and diet adequacy. J. Anim. Sci. 70:3578-3596.

Kosikowski, F. V., and V. V. Mistry. 1997. Page 379 in Cheese and Fermented Milk Foods. Vol. 1: Origins and Principles. F. V. Kosikowski, LLC, Westport, CT.

Licitra, G., T. M. Hernandez, and P. J. Van Soest. 1996. Standardization of procedure for nitrogen fractionation of ruminant feeds. Anim. Feed Technol. 57:351-354.

Licitra, G., G. Portelli, P. Campo, G. Longombardo, G. Farina, S. Carpino, and D. M. Barbano. 1998. Technology to produce Ragusano cheese: A survey. J. Dairy Sci. 81:3343-3349.

Licitra, G., P. Campo, M. Manenti, G. Portelli, S. Scuderi, S. Carpino, and D. M. Barbano. 2000a. Composition of Ragusano cheese during aging. J. Dairy Sci. 83:404-411.

Licitra, G., G. Leone, F. Amata, and D. Mormorio. 2000b. Heritage and landscape: The art of traditional cheese-making Ragusano. Federico Motta Editor. Consorzio Ricerca Filiera Lattiero-Casearia, s.p. $25 \mathrm{Km} \mathrm{5,} 97100$ Ragusa, Italy.

Melilli, C., D. M. Barbano, G. Licitra, G. Tumino, G. Farina, and S. Carpino. 2003. Influence of presalting and brine concentration on salt uptake by Ragusano cheese. J. Dairy Sci. 86:1083-1100.

O'Mahony, M. 1986. Sensory Evaluation of Food. Marcel Dekker, Inc. New York, NY. 
Panfili, G., P. Manzi, and L. Pizzoferrato. 1994. High-performance liquid chromatographic method for the simultaneous determination of tocopherols, carotenes, and retinol and its geometric Isomers in Italian cheeses. Analyst. 119:1161-1165.

Phillips, L. G., M. L. McGiff, D. M. Barbano, and H. T. Lawless. 1995. The influence of fat on the sensory properties, viscosity, and color of lowfat milk. J. Dairy Sci. 78:1258-1266.

SAS User's Guide: Statistics, Version 8. Edition. 1999. SAS Inst., Inc., Cary, NC.
Urbach, G. 1990. Effect of feed on flavor in dairy products. J. Dairy Sci. 72:3639-3650.

Van Soest, P. J., J. B. Robertson, and B. A. Lewis. 1991. Methods for dietary fiber, neutral detergent fiber, and nonstarch polysaccharides in relation to animal production. J. Dairy Sci.74:3583-3597.

Wigan, F. 1951. Judging milk products. P. V. Turk Dairy Publ., Sydney, Australia. 